\title{
Rebekka Studler
}

\section{Cognitive cultural models at work: The case of German-speaking Switzerland}

https://doi.org/10.1515/gcla-2017-0007

\begin{abstract}
In the German-speaking part of Switzerland, people use Swiss German and High German side by side in their daily life. This situation gives rise to various attitudes towards both of these two varieties. Interestingly, some of these attitudes seem to be partly in conflict. The aim of this paper is to show that these attitudes are not necessarily conflicted but rather that such attitudes normally have a multidimensional character. Multidimensional attitudes can be traced back to multidimensional mental models on which people naturally draw. In applying Berthele's (2010) cluster model, which combines Geeraerts's (2003) rationalist and romantic models for standardization, the paper illustrates, based on a recent study, which mental models have to be operative to conceptualize the complex frames of the two varieties in use. Additionally, recent shifts in the attitudinal climate in Switzerland indicate that these cognitive cultural models are not static but are subject to dynamic processes.
\end{abstract}

Keywords: multidimensional attitudes, cognitive cultural models, rationalist and romantic models of standardization, conceptual metaphors

\section{Introduction}

The merits of cooperation between cognitive linguistics and sociolinguistics are self-evident and have led to an increasing number of studies in the field of cognitive sociolinguistics (cf. Kristiansen \& Dirven 2008, Pütz, Robinson \& Reif 2014). It is well known both in cognitive linguistics and in folk linguistics (cf. Niedzielski \& Preston 2000) that people draw on mental models to structure and comprehend social reality. Research on language attitudes shows how people perceive and evaluate languages, not only as linguistic structures but also as social practice. Cognitive linguistics provides the accurate mental models to explain how people categorize and frame their experience and, hence, govern their evaluations. In including investigation of "the meaning of variation" (Geeraerts \& Kristiansen

Rebekka Studler: Universität Basel. E-mail: rebekka.studler@unibas.ch 
2014: 211), the mental models of cognitive linguistics contribute to the question of how people mentally represent linguistic variation and diversity, for example by means of conceptual metaphors and cognitive cultural models to frame the perception and evaluation of language varieties.

This paper shows how cognitive cultural models and their corresponding conceptual metaphors account for the attitudinal climate of a society with two varieties in use. In the paper, I demonstrate how conflicting attitudes can be traced back to a multidimensional mental model in scrutinizing current language attitudes towards the standard variety (High German) and the nonstandard variety (Swiss German) expressed in the diglossic setting of German-speaking Switzerland.

For that purpose, Geeraerts's (2003) well-known models of standardization, the rationalist and the romantic model, turn out to be especially helpful. Bringing these two models together in a cluster model (Lakoff 1987), as Berthele (2010) suggests, adequately shapes the interpretation of the complex language situation in German-speaking Switzerland. Drawing on recent quantitative and qualitative data collected via a questionnaire with 750 participants, the paper discusses the current attitudes toward High German and Swiss German along the lines of the rationalist and the romantic models.

The paper is structured as follows. Section 2 provides basic information on language attitudes in German-speaking Switzerland and the general set-up of the present study. In Section 3, I sketch the cognitive cultural models applied in this paper to capture the case of German-speaking Switzerland. Section 4 shows how Swiss German and High German are conceptualized along the lines of these cultural models, drawing on the results of the current study. Section 5 closes the paper with some concluding remarks.

\section{Attitudes toward standard and nonstandard varieties: The case of German-speaking Switzerland}

In the German-speaking part of Switzerland, people use two language varieties side by side in daily life, Swiss German and High German. ${ }^{1}$ This diglossic

1 I use the term "High German" as principally used in folk metalanguage to refer to the standardized variety, and "Swiss German", interchangeably with "dialect” and "vernacular", to refer to the nonstandard variety encompassing all Alemannic dialects spoken in Switzerland. 
language situation ${ }^{2}$ is responsible for a variety of attitudes. Swiss German is the beloved mother tongue, and unsurprisingly attitudes towards it are mainly positive. Attitudes towards High German are more complex. On the one hand, they tend to be positive, since High German is generally held in high esteem, thanks to a high norm awareness vis-à-vis the standardized variety. On the other hand, they are negative - after all, High German is not the primary colloquial language and is seen as the language of achievement in school (cf. e.g., Sieber \& Sitta 1986, Häcki Buhofer \& Studer 1993). Furthermore, German is a pluricentric language (Clyne 1995, Ammon 1991) with theoretically equal standard varieties for Germany, Austria, and Switzerland. Despite this theoretical equality, Swiss Germans often evaluate their language abilities as inferior to those of Germans (Scharloth 2005). Moreover, attitudes towards High German are notably intertwined with attitudes towards its speakers, namely Germans, thereby exposing the somewhat conflictual relationship between Swiss and Germans in general (Schläpfer et al. 1991).

However, these outcomes mostly date back to studies conducted in the 1980s and 1990s. A study based on data collected in 2013/14 aims to investigate whether these findings still apply and, if not, in what way the attitudes have changed. The data of this study were collected in a folk linguistic framework (cf. e.g., Niedzielski \& Preston 2000). The participants were informed about the research question and the purpose of the study, and accordingly provided information about their opinions, beliefs, feelings, and attitudes regarding the language situation in Switzerland. Furthermore, a mixed methods design was applied (cf. e.g., Teddlie \& Tashakkori 2009). The data were collected through a questionnaire with 60 closed and seven open questions, providing not just quantitative data but also a large amount of qualitative data. In total, 750 people from highly diverse sociolinguistic backgrounds participated in this part of the study. In addition, in-depth interviews, ideally taking the form of narratives, were conducted with a small subsample along the sociolinguistic dimensions of gender, age, and education. The questions in the survey and in the interviews were structured around the five domains of 1. language socialization, 2. language competence, 3. perception and judgments, 4. attitudes and opinions, and 5. language policy. For the purpose of this paper, I concentrate on the results of the questionnaire.

2 Whether the language situation in German-speaking Switzerland should be described as diglossia (Ferguson 1959) or rather as bilingualism is the subject of a long-lasting debate. Rather than enter into this discussion here, I refer readers to details in, for example, Werlen (1998) and Haas (2004), and, for a folk linguistic approach, Studler (2017). 
Whereas the present study by and large confirms the outcomes of previous research, it reveals that the attitudes towards High German are in general less negative than assumed, and positive attitudes seem to have gained ground over the last two or three decades (cf. for a similar outcome Christen et al. 2010). Apart from this, however, most informants make positive as well as negative statements and thus seem to be inconsistent. Interestingly, people seem to deal surprisingly well with these inconsistencies. The pressing questions are, thus, where these conflicting attitudes arise from and how they manage to exist side by side. The next section introduces the mental models applied in order to answer these questions.

\section{Mental models for language attitudes: Theoretical background}

To come to an understanding of the complex attitudinal landscape of Germanspeaking Switzerland, we first have to acknowledge that the multidimensional character of languages can cause multidimensional attitudes. There is no such thing as the attitude towards a particular object; attitudes are naturally multidimensional precisely because the objects of attitudes are multidimensional (cf. e.g., Preston 2004, and for High German in Switzerland, Christen et al. 2010, Sieber 2013): (standard and nonstandard) languages fulfill various functions, and people use them in different contexts with different people for different purposes. Hence, only a multidimensional mental model is capable of shaping the multidimensionality of languages or, more specifically, of the attitudes to them.

Since language attitudes are commonly also evoked by the ideologies of a community, such models need to be able also to encompass the conceptual link between language and ideology or, more generally, between language and culture (cf. e.g., Kristiansen \& Dirven 2008: 5). In regarding culture as shared knowledge, a cognitive approach aims to understand how this cultural knowledge is mentally organized (Quinn \& Holland 1987: 4). Cognitive cultural models, that is, "the more or less coherent sets of concepts that cultures use" (Geeraerts \& Kristiansen 2014: 208), illuminate how people interpret their experience and govern their behavior.

To capture the cognitive cultural concepts responsible for the language attitudes in German-speaking Switzerland, the models of standardization introduced by Geeraerts (2003) are particularly promising. Geeraerts's pioneering work suggests two models of standardization, the rationalist model and the romantic model. The rationalist model of standardization, rooted in the Enlightenment thinking of the $18^{\text {th }}$ century, conceptualizes language as a medium of communication. The standard language is seen as a neutral medium of social participation and 
language variation as an impediment to emancipation. According to the romantic model, rooted in the romantic view of the $18^{\text {th }}$ and $19^{\text {th }}$ centuries, language is a medium of expression. In this model, the standard language is seen as a medium of social exclusion and language variation as a possibility for expressing different identities (Geeraerts 2003: 40). ${ }^{3}$ Geeraerts emphasizes that these two models are not necessarily exclusive but rather may partly coalesce. However, Berthele (2010) proposes systematically combining these two models into a cluster model (cf. Lakoff 1987) to shape the language situation in German-speaking Switzerland. By conceptualizing language as a medium of communication, the rationalist model serves best to account for the perception and evaluation of High German; by conceptualizing language as a medium of expression, the romantic model ideally captures the case for Swiss German. Furthermore, the cultural models of standardization are fed by conceptual metaphors (Lakoff \& Johnson 1980), revealing the ideological or prototypical nature of standard and nonstandard varieties. Table 1 provides the conceptual metaphors identified by Berthele (2010) as corresponding to the respective model.

Table 1: Conceptual metaphors corresponding to the cultural models of standardization according to Berthele (2010: 268).

\begin{tabular}{ll}
\hline $\begin{array}{l}\text { Rationalist model } \\
\text { Language is... }\end{array}$ & $\begin{array}{l}\text { Romantic model } \\
\text { Language is... }\end{array}$ \\
\hline a TOOL, KEY, BRIDGE & the SOUL OF A PEOPLE, a MOTHER \\
\hline $\begin{array}{l}\text { a BOND, GLUE, TIE } \\
\text { of the nation }\end{array}$ & $\begin{array}{l}\text { a BOND, GLUE, TIE } \\
\text { of the language community }\end{array}$ \\
\hline a balanced STRUCTURE, a BUILDING & a HOME \\
\hline a RESOURCE - raw material & a RESOURCE - cultural heritage \\
\hline a BARRIER - dialects & a BARRIER - standard \\
\hline
\end{tabular}

Evidently, some of the identified metaphors strictly correspond to one of the two models (e.g., STRUCTURE for the rationalist model, HOME for the romantic model), whereas others exist in both models (e.g., BOND or RESOURCE). The next section draws on the results of the present study to elaborate on this point.

3 These models have been adapted in many ways to make them fit different concerns, e.g., language conflicts (Dirven \& Pütz 2007), language policy (Soares 2015), and globalization and world languages (Dirven \& Polzenhagen 2004). 


\section{Results and discussion}

In the remainder of this paper, I present some results of the present study illustrating the folk conceptualizations of Swiss German and High German along the cluster model of Berthele (2010). The mapping of these two varieties to the two components of the model accommodates the prima facie inconsistent attitudes. The last subsection is dedicated to pointing out some shifts in the perception of High German.

\subsection{Results in support of the romantic model}

In the romantic model, language is conceptualized as a medium of expression. In German-speaking Switzerland, nothing accomplishes this purpose better than Swiss German. The results of the present study, which will be discussed in the following, suggest that Swiss German is conceptualized as HOME and as the SOUL OF A PEOPLE. This is also reflected in the conceptualization of Swiss German as a BOND within the Swiss German speech community, and related to the RESOURCE metaphor in the sense of a shared cultural heritage fulfilling the purpose of being an IDENTITY MARKER. High German, on the other hand, poses a THREAT ${ }^{4}$ to the local identity of Swiss Germans and their local cultural heritage - and to Swiss German itself, which amplifies the cultivation of Swiss German.

The participants in the study seemed to have a strong urge to state their views on Swiss German. Even if not explicitly asked for, every open question was taken as an opportunity to express their perception and evaluation of the language and the language situation. Participants had the opportunity to comment and elaborate on their language socialization and their stance on popular opinions and stereotypes, as well as to provide considered answers to some of the closed questions. It was found that the statements regarding the nonstandard variety were predominantly used to convey a romantic conceptualization of language. Table 2 provides some examples of the range of the answers.

To explore this in greater detail, one of the open questions has proved to be particularly informative regarding the remarkably high degree of conceptualizing Swiss German in accordance with the romantic model. Participants were asked to elaborate on their answers to the closed question 'Do you think that engagement with language is important?' in an open follow-up question ('What

4 For the conception of standard and international languages, such as global English, as a THREAT, cf. Geeraerts (2003: 54). 
Table 2: Conceptualizations of Swiss German in the romantic model.

\begin{tabular}{|c|c|}
\hline Home & "my dialect is my home", "in my dialect, I feel at home" \\
\hline Loyalty & "I adhere to my dialect", "we definitely won't adapt" \\
\hline Language of a people/mother & $\begin{array}{l}\text { "our dialect is our language", "because we are Swiss and not } \\
\text { Germans", "only Swiss German is my mother tongue" }\end{array}$ \\
\hline Secret language & $\begin{array}{l}\text { "I like the fact that the Germans don't understand Swiss } \\
\text { German", "Swiss German is kind of a secret language" }\end{array}$ \\
\hline Cultural resource & $\begin{array}{l}\text { "dialect represents our origin and culture", "dialect is also a } \\
\text { Swiss cultural asset we have to maintain" }\end{array}$ \\
\hline Dialect cultivation & $\begin{array}{l}\text { "dialect is part of our culture and should be preserved", "our } \\
\text { dialect has to be cultivated and used" }\end{array}$ \\
\hline Bond of the speech community & $\begin{array}{l}\text { "Our dialect needs to be fostered. This is what gives the region } \\
\text { cohesion!" }\end{array}$ \\
\hline Identity marker & $\begin{array}{l}\text { "dialects are a typical sign of 'Swissness'. Swiss people are } \\
\text { proud of it", "Swiss German is identity-establishing" }\end{array}$ \\
\hline
\end{tabular}

was the reason for your answer to the previous question?'). The most frequent reasons given for the importance of engagement with language referred to cultural and identity aspects of language (more than 250 statements), closely followed by language/dialect cultivation (approximately 170 statements). ${ }^{5}$ The participants thus were seen to conceive language exactly corresponding to the concept of 'language as a medium of expression' with all its related conceptual metaphors (see Table 1). The following examples help to illustrate this point.

(1) Sprache hat auch mit Heimat zu tun, gehört zu den Wurzeln eines Menschen, prägt teilweise auch die Identität etc.

'Language also has to do with home, belongs to the roots of a person, partly also influences the identity, etc.'

(2) Unsere Dialekte bergen einen reichen Schatz an Kommunikation, sind sehr präzise und detailliert. Es wäre kulturell und historisch ein Jammer, diesen Schatz zu verlieren.

'Our dialects contain a rich treasure of communication, are very precise and detailed. Culturally and historically, it would be a pity to lose this treasure.'

5 Only statements concerning the importance of language in general, for example in the sense of fundamental linguistic research, elicited a similar number of answers (230 statements). 
(3) Der Dialekt ist ein wichtiger Teil unserer Kultur, wenn dieser ausstirbt, stirbt auch ein Teil von uns.

'The dialect is an important part of our culture, when it dies out, a part of ourselves dies too.'

(4) Dialekte sind Volks- und Kulturgut, der Dialekt als Muttersprache ist Herzens- und Gefühlsprache und darf deshalb nicht zugunsten des Hochdeutschen verloren gehen!

'Dialects are ethnic and cultural assets, the dialect as a mother tongue is a language of the heart and the feelings, and therefore must not be lost in favor of High German.'

(5) Ich finde es sehr wichtig, dass der Schweizerdialekt weiter gepflegt wird und nicht alles in die Standardsprache gewechselt wird.

'I find it very important that the Swiss dialect is cultivated further and that not everything is changed into standard language.'

Example (3) not only demonstrates that language is a cultural resource but also implies that language loss is often equated with cultural loss and indeed with identity loss. Examples (4) and (5) also highlight the alleged "threat" coming from High German, highlighted even further in statement (6).

(6) Hochdeutsch bedeutet einen gewissen Verlust von Identität.

'High German means a certain loss of identity.'

This threat is assumed to affect not merely dialectal diversity but also local cultural identity.

\subsection{Results in support of the rationalist model}

The results of the present study confirm the conceptualization of High German in the rationalist model in many respects. High German is seen as a TOOL, a KEY, or a BRIDGE to interact with people who do not speak Swiss German. Mastery of High German extends communication and social participation - not only in the German-speaking world but also across the language borders in multilingual Switzerland, as well as with foreigners in German-speaking Switzerland. Also, given that High German is the predominant written language in Switzerland and thus embodies a literary and cultural cohesion, High German is undoubtedly perceived as a BOND to connect Swiss Germans with the rest of the Germanspeaking world. Furthermore, not only external factors but also the language inherent values of High German are invoked. High German is conceptualized as 
a perfect BUILDING best qualified to serve as a "lingua franca" in this context, thanks to its logical STRUCTURE. ${ }^{6}$ Swiss German, on the other hand, is, at least to some extent, conceptualized as a BARRIER. Swiss German speakers are aware of its limited possibilities for participating in a globalized (German-speaking) world, and assume that Swiss German lacks the necessary logical STRUCTURE to be a language of wide application.

The conceptualization of High German as arranged in the rationalist model is omnipresent in the current study. For the sake of brevity, I will concentrate on responses to the open question on why people do not dispute the importance of High German competence. ${ }^{7}$ By far the most prevalent answers were, first, High German as medium to write and read (approximately 200 statements), second, High German as a medium for communication in general (approximately 200 statements), and third, communication with Germans/Austrians in particular, including the recognition of an all-German language area (approximately 150 statements). Additionally, many participants reported that High German is an integral part of professional life (approximately 100 statements). Another 40 or so statements evaluated High German positively for its logical structure - in contrast to Swiss German (see next paragraph). Table 3 provides some examples of these conceptualizations.

Swiss German, on the other hand, is perceived as lacking a logical structure and not as a language of wider communication. Furthermore, Swiss German is perceived as a barrier between the language borders (see Table 4).

Swiss German can also be seen as a barrier for speakers of different dialects, a somewhat unexpected finding, since Swiss German dialects are normally recognized as qualified for mutual understanding. Nevertheless, in some statements, High German is referred to as "lingua franca", "common basis", "foundation stone" that enables misunderstandings among dialect speakers to be avoided.

In summary, analysis of the folk models that underlie the attitudinal statements of the present study reinforces the adequacy of Berthele's cluster model for German-speaking Switzerland. In combining the two cognitive cultural models of standardization, the conflicting attitudes induced by the various purposes of the two varieties find a convenient explanation. As the following statement neatly expresses, even people who state a high familiarity and no fear of contact with High German admit that they experience ambivalent feelings towards High

6 For a skeptical review of linking the concept of LANGUAGE AS A TOOL OF WIDER COMMUNICATION to the alleged inherent logical values of a language, cf. Dirven \& Polzenhagen 2004: 14. 7 In the preceding closed question, 68\% estimated High German competence as very important and another $25 \%$ as rather important. 
Table 3: Conceptualizations of High German in the rationalist model.

\begin{tabular}{|c|c|}
\hline Medium & $\begin{array}{l}\text { "it is a medium of communication", "languages are mediators to relationships, } \\
\text { without languages [there can be] no relationships", "access to German literature } \\
\text { and media" }\end{array}$ \\
\hline Bridge & $\begin{array}{l}\text { "High German often serves as a bridge across dialects and different } \\
\text { language areas of German", "High German is the language with which we } \\
\text { communicate across national and dialectal borders" }\end{array}$ \\
\hline Key & $\begin{array}{l}\text { "language as a key to the world", "High German opens the doors to } \\
\text { literature and better articulateness" }\end{array}$ \\
\hline $\begin{array}{l}\text { Tool } \\
\text { of (wider) } \\
\text { communication }\end{array}$ & $\begin{array}{l}\text { "communication with people who do not understand dialects", "in the } \\
\text { globalized world High German is an important language too", "High } \\
\text { German is simply the 'lingua franca' in the German-speaking world" }\end{array}$ \\
\hline Bond & $\begin{array}{l}\text { "we are part of the 'all-German' language area, the common language and } \\
\text { literature of which is High German", } \\
\text { "we are part of the German-speaking cultural area", "High German } \\
\text { connects us internationally" }\end{array}$ \\
\hline $\begin{array}{l}\text { Balanced } \\
\text { structure/building }\end{array}$ & $\begin{array}{l}\text { "very clear", "systematized", "right and wrong exist", "beautiful, } \\
\text { 'sophisticated' language with style","in certain situations, I get to the point } \\
\text { more easily with High German", "High German is better qualified to convey } \\
\text { and discuss complex content and topics" }\end{array}$ \\
\hline
\end{tabular}

Table 4: Conceptualizations of Swiss German in the rationalist model.

\begin{tabular}{ll}
\hline Lack of structure & $\begin{array}{l}\text { "Swiss German is simply not a real language", "Swiss German is just a } \\
\text { dialect with neither grammar nor orthography", "Grammatically, Swiss } \\
\text { German does not exist at all", "Swiss German is not a codified language" }\end{array}$ \\
\hline Barrier & $\begin{array}{l}\text { "the dialect is locally very limited", "Switzerland is geographically too small } \\
\text { an area to rely only on the dialect", "Switzerland is small ... and it would be } \\
\text { a bit boring to talk only to Swiss people", "to be able to talk to people other } \\
\text { than German-speaking Swiss helps counter parochial small-mindedness" }\end{array}$ \\
\hline
\end{tabular}

German, at least in specific situations, and that they shape different identities in respect of the two varieties.

(7) Da ich von Beruf aus sehr viel Hochdeutsch spreche, macht es für mich keinen grossen Unterschied. Nur in intimen Momenten da komme ich mir selber plötzlich fremd vor, als wäre ich nicht ganz ich, wenn ich Hochdeutsch rede. Oder wenn ich ganz müde bin. Jedenfalls habe ich, wenn ich Hochdeutsch spreche, eine andere Identität, eine intellektuellere. Die Schweizer ist mehr urchig und bäurisch erdig. 
'Since I speak High German very often in my job, it does not make a big difference to me. Just in intimate moments I suddenly feel like a stranger, as if I were not totally myself when speaking High German. Or when I am very tired. In any case, when I speak High German, I have another identity, more of an intellectual one. The Swiss [identity] is quainter and rustic earthy.'

Apart from confirming previous findings, the present study reveals some recent trends. In the following, I show that these trends can be explained within the same framework.

\subsection{Recent trends: A greater ease of handling and a touch of romance for High German}

Although strong stereotypes and established ideologies persist with regard to High German in German-speaking Switzerland, there is an observable shift in that High German is seen more positively than originally assumed. A majority of $63 \%$ perceives High German as a beautiful language, 60\% report that they actually like to speak High German and as many as $88 \%$ state that their competences are (rather or very) good. At least for part of the population, High German has become a dynamic colloquial language (47\% report using High German frequently). This seems to have induced a shift in the recognition of High German. The conceptualization of High German as a medium of communication is more pronounced than expected and probably reflects the ongoing changes in people's professional and private lives. However, not only is High German called a "lingua franca" and a prerequisite for the globalized job market, but it also serves as a BOND to connect the Swiss people to the whole German-speaking world. As has been shown above, this is in principle already incorporated in the rationalist model for High German. Yet, the strong link to the cultural aspects of this bond also permits the shaping of an all-German cultural identity. This shows that High German is not only conceptualized as a RESOURCE in the sense of the rationalist model (as a raw material) but also as a cultural RESOURCE in the sense of the romantic model. Moreover, the strong stereotype that High German is undoubtedly suitable for conveying complex content but not for acting as a language of expression is challenged. A majority of 53\% disagreed with the popular opinion that High German is not appropriate for expressing feelings - thus ushering in the notion that High German is also a language of the heart. Furthermore, although there is a widespread view that High German is a foreign language (cf. Studler 2017), at least a few statements point in the direction of High German perceived 
as a mother tongue ("High German is part of my mother tongue", "It is our "written mother tongue", "German as mother tongue in my passport", "my mother tongue German as a language with two varieties") and accordingly conceptualized as HOME. I conclude this analysis with the following illuminating statement.

(8) Deutsch, ob Schwiizerdütsch oder Hochdeutsch, hat für mich mit Heimat, mit Identifikation zu tun. Die deutsche Sprache ist viel mehr als Kommunikationsvehikel, ist Kultur und Kulturträgerin. Und wenn ich ein Teil dieser kulturellen Welt sein will, muss ich mich in dieser Sprache daheim fühlen können und wollen.

'For me, German, whether Swiss German or High German, has to do with home, with identification. The German language is more than a vehicle for communication, it is culture and a carrier of culture. If I want to be part of this cultural world, I have to be able and willing to feel at home in this language.'

\section{Conclusion}

This paper aims to show how people handle conflicting attitudes towards standard and nonstandard varieties of German. I advocate moving away from the idea that attitudes are one-dimensional and instead acknowledging that they are often multidimensional, thus revealing the ability of lay people (and experts) to conceptualize and construct - based on complex cognitive (cultural) models - their linguistic and social reality. As has been shown, the attitudes and their various strategies of verbalization can be traced back to the respective mental concepts and therefore need to be understood as effects of the coexistence of these underlying models. Precisely because these ambivalent attitudes appear not to be exceptional but rather the rule, the mostly peaceful coexistence between them can be explained by the fact that the concept of High German (and Swiss German) is not one-dimensional but is fostered by multidimensional mental models (cf. also Christen et al. 2010, Sieber 2013). In particular, the language ideologies in German-speaking Switzerland can be explained best by Geeraerts's (2003) cultural models of language standardization, i.e., the rationalist model and the romantic model. This paper has shown that combining them into a cluster model (Lakoff 1987), as Berthele (2010) suggests, enables the prima facie conflicting attitudes to be accommodated.

The strong stereotypes for both Swiss German and High German remain, rendering the cluster model in many facets perfectly suitable for the language situation in today's German-speaking Switzerland. However, that “[...] these 
models are by no means static [...] [but] have to be understood as dynamic entities of situated cognition" (Berthele 2010: 274) would seem to represent the current situation perfectly, insofar as High German is apparently undergoing a lively process of expanding into the romantic model, at least to some extent.

\section{References}

Ammon, Ulrich. 1991. Die Plurizentrizität der deutschen Sprache. In Bjørn Ekmann, Hubert Hauser \& Peter Porsch (eds.), Deutsch - eine Sprache? Wie viele Kulturen?, 14-34. Kopenhagen/München: Fink.

Berthele, Rapael. 2010. Investigations into the folk's mental models of linguistic varieties. In Dirk Geeraerts, Gitte Kristiansen \& Yves Peirsman (eds.), Advances in cognitive sociolinguistics, 265-290. Berlin \& New York: Mouton de Gruyter.

Christen, Helen, Manuela Guntern, Ingrid Hove \& Marina Petkova. 2010. Hochdeutsch in aller Munde: Eine empirische Untersuchung zur gesprochenen Standardsprache in der Deutschschweiz. Stuttgart: Steiner.

Clyne, Michael. 1995. The German language in a changing Europe. Cambridge: University Press.

Dirven, René \& Frank Polzenhagen. 2004. Rationalist or romantic model in language policy and globalisation. Essen: LAUD A. http://www.linse.uni-due.de/laud-downloadliste/articles/ rationalist-or-romantic-model-in-language-policy-and-globalisation.html?file=tl_files / laud/A622.pdf. (4 July, 2017.)

Dirven, René \& Martin Pütz. 2007. Language conflict seen from the perspective of the rationalist and romantic models: New developments. Southern African Linguistics and Applied Language Studies 25(3). 303-317.

Ferguson, Charles A. 1959. Diglossia. Word 15. 325-340.

Geeraerts, Dirk. 2003. Cultural models of linguistic standardization. In René Dirven, Roslyn Frank \& Martin Pütz (eds.), Cognitive models in language and thought: Ideology, metaphors and meanings, 25-68. Berlin, New York: Mouton de Gruyter.

Geeraerts, Dirk \& Gitte Kristiansen. 2014. Cognitive linguistics and language variation. In Jeanette Littlemore \& John R. Taylor (eds.), The Bloomsbury companion to cognitive linguistics, 202-217. London, New Delhi, New York, Sydney: Bloomsbury.

Haas, Walter. 2004. Die Sprachsituation der deutschen Schweiz und das Konzept der Diglossie. In Helen Christen (ed.), Dialekt, Regiolekt und Standardsprache im sozialen und zeitlichen Raum: Beiträge zum 1. Kongress der Internationalen Gesellschaft für Dialektologie des Deutschen, Marburg/Lahn, 5. - 8. März 2003, 81-110. Wien: Edition Praesens.

Häcki Buhofer, Annelies \& Thomas Studer. 1993. Zur Entwicklung von Sprachdifferenzbewusstsein und Einstellung zu den Varianten des Deutschen in der deutschen Schweiz. In Bulletin CILA 58. 179-200.

Kristiansen, Gitte \& René Dirven (eds.). 2008. Cognitive sociolinguistics: Language variation, cultural models, social systems. Berlin, New York: Mouton de Gruyter.

Lakoff, George. 1987. Women, fire, and dangerous things: What categories reveal about the mind. Chicago, London: University of Chicago Press.

Lakoff, George \& Mark Johnson. 1980. Metaphors we live by. Chigago: University of Chicago Press. Niedzielski, Nancy A. \& Dennis R. Preston. 2000. Folk linguistics. Berlin: de Gruyter. 
Pütz, Martin, Justyna A. Robinson \& Monika Reif (eds.). 2014. Cognitive sociolinguistics: Social and cultural variation in cognition and language use. Amsterdam, Philadelphia: John Benjamins.

Preston, Dennis R. 2004. Language with an attitude. In John K. Chambers, Peter Trudgill \& Natalie Schilling-Estes (eds.), The handbook of language variation and change, 40-66. Oxford/Malden: Blackwell.

Scharloth, Joachim. 2005. Zwischen Fremdsprache und nationaler Varietät: Untersuchungen zum Plurizentrizitätsbewusstsein der Deutschschweizer. In Rudolf Muhr (ed.), Standardvariationen und Sprachideologien in verschiedenen Sprachkulturen der Welt/ Standard Variations and Language Ideologies in Different Language Cultures around the World, 21-44. Frankfurt am Main \& Bern: Peter Lang.

Schläpfer, Robert, Jürg Gutzwiller \& Beat Schmid. 1991. Das Spannungsfeld zwischen Mundart und Standardsprache in der deutschen Schweiz: Spracheinstellungen junger Deutsch- und Welschschweizer. Aarau: Sauerländer.

Sieber, Peter \& Horst Sitta. 1986. Mundart und Standardsprache als Problem der Schule. Aarau, Frankfurt a. M., Salzburg: Sauerländer.

Sieber, Peter. 2013. Probleme und Chancen der Diglossie - Einstellungen zu Mundarten und Hochdeutsch in der Deutschschweiz. In Brigit Eriksson, Martin Luginbühl \& Nadine Tuor (eds.), Sprechen und Zuhören - Gefragte Kompetenzen? Überzeugungen zur Mündlichkeit in Schule un Beruf, 106-136. Bern: hep verlag.

Soares da Silva, Augusto. 2015. Cultural cognitive models of language variation: Romanticism and rationalism in language policy debates about the unity/diversity of European and Brazilian Portuguese. In Jocelyne Daems, Eline Zenner, Kris Heylen, Dirk Speelman \& Hubert Cuyckens (eds.), Change of paradigms - new paradoxes: Recontextualizing language and linguistics, 253-274. Berlin, Boston: Mouton de Gruyter.

Studler, Rebekka. 2017. Diglossia and bilingualism: High German in German-speaking Switzerland from a folk linguistic perspective. Revue transatlantique d'études suisses 6/7 (2016/2017). 39-57.

Teddlie, Charles \& Abbas Tashakkori. 2009. Foundations of mixed methods research: Integrating quantitative and qualitative approaches in the social and behavioral sciences. Los Angeles, London, New Delhi, Singapore, Washington DC: Sage.

Quinn, Noami \& Dorothy Holland. 1987. Culture and cognition. In Noami Quinn \& Dorothy Holland (eds.), Cultural models in language and thought, 3-40. Cambridge: Cambridge University Press.

Werlen, Iwar. 1998. Mediale Diglossie oder asymmetrische Zweisprachigkeit? Mundart und Hochsprache in der deutschen Schweiz. Babylonia 1. 22-35. 